\title{
Plague and listeriosis: current outbreaks, and an historical South African connection
}

\author{
John Frean, ${ }^{1}$ Lucille Blumberg, ${ }^{1}$ Kerrigan McCarthy, ${ }^{2}$ Juno Thomas ${ }^{3}$ \\ ${ }^{1}$ Centre for Emerging Zoonotic and Parasitic Diseases, \\ ${ }^{2}$ Division of Public Health Surveillance and Response, \\ ${ }^{3}$ Centre for Enteric Diseases \\ National Institute for Communicable Diseases, Johannesburg, South Africa \\ *Corresponding author, email:johnf@nicd.ac.za
}

The extensive outbreak of plague in Madagascar, which started in August 2017, attracted world-wide attention. Sensational headlines speculating on the return of the 'Black Death' of medieval times, reflected general lack of awareness that plague is endemic in Madagascar, and indeed, in a number of other African countries. Madagascar records up to 400 cases of plague, mainly bubonic, in its highland plateau region annually between September and April.' The current major outbreak of urban pneumonic plague is an unusual occurrence, amplified by rapid dissemination of highly infectious patients by public transport. The outbreak was declared as 'contained' by the Madagascar Ministry of Health at the beginning of December 2017. Between 1 August and 26 November 2017, 2417 confirmed, probable and suspected cases were reported from 57 of 114 (50\%) districts in Madagascar. There were 209 deaths, with a case fatality rate of $9 \%$. Most cases ( $1854,77 \%$ ) were clinically classified as pneumonic plague, 355 (15\%) were bubonic, one was septicaemic, and the remainder have not yet been classified. There has been no international spread outside Madagascar, risk of spread at regional and global level is low, and no travel or trade restrictions were recommended by the World Health Organization. ${ }^{2}$

African countries that have reported plague in the last quarter century are Algeria, Botswana, Democratic Republic of Congo, Kenya, Malawi, Mozambique, Namibia, Uganda, Tanzania, Zambia, and Zimbabwe [3]. ${ }^{3}$ Plague was previously endemic in South Africa as well, but the last human cases were reported in 1982, in Coega, Eastern Cape Province. ${ }^{4}$ Plague had been introduced to the region at the turn of the $20^{\text {th }}$ century during the world-wide third pandemic of plague, and after causing outbreaks in several South African ports, spread inland and became established in indigenous rodents, especially gerbils. During the field investigation of plague outbreaks in the 1920s, JH Harvey Pirie, a bacteriologist working at the SA Institute for Medical Research (SAIMR, the NICD's predecessor), described a bacterial infection that caused widespread mortality among wild rodents. He gave it the name 'Tiger River disease' after the site in the eastern Orange Free State where it was first noted, and characterised the organism as a small Gram-positive bacillus that produced striking liver pathology in rodents. ${ }^{5}$ Harvey Pirie named it Listerella hepatolytica, in honour of Joseph Lister, the pioneer of surgical antisepsis. On its submission to the National Type Collection in London, the organism was noted to be similar to one found by Dr EG Murray in Cambridge in 1924, which caused fatal infections in young rabbits. ${ }^{6}$ Murray called it Bacterium monocytogenes, and several other names were subsequently used, including Listerella monocytogenes. ${ }^{7}$ When, in 1939, it was noted that the name Listerella had been earlier applied to other organisms, Harvey Pirie proposed that the genus be changed to Listeria, and he is credited as one of the taxonomic authors, thus: 'Listeria monocytogenes (Murray 1926) Pirie 1940.8 (A footnote to this story is the later speculation that Harvey Pirie intended to name his organism for Sir Spencer Lister, then Director of the SAIMR, rather than Lord Lister, 9 but reading his original account makes it clear that this was not so. ${ }^{5}$ Sir Spencer died of a heart attack while reading in the Institute's library on September 6, 1939, the day that South Africa declared war on Germany. This was also the week of the Third International Congress for Microbiologists in New York, where the Listerella nomenclature was discussed. Harvey Pirie was appointed acting director of the SAIMR until Dr Eustace Cluver took office in mid-1940. ${ }^{10}$ )

As plague in Madagascar subsides, the smouldering listeriosis outbreak in South Africa continues. As of 12 January 2018, 748 laboratory-confirmed cases have been reported since the beginning of $2017 .{ }^{11}$ Of the 160 cases with a known outcome, $67(42 \%)$ have died. Gauteng Province has had most cases (about 60\%), followed by the Western Cape and KwaZulu-Natal provinces. Where age was reported, $39 \%$ of cases were neonates (less than 28 days of age), almost all early-onset disease. In its tendency to selectively cause invasive infections with high case fatality rates, listeriosis is an unusual foodborne illness, with a highly variable incubation period. Another problem in dealing with outbreaks is the ubiquity of the organism. Listeria monocytogenes has been isolated from nearly all kinds of plant and animal foods. ${ }^{12}$ Typically, sporadic listeriosis cases are associated with consumption of delicatessen-style meat and cheese products, but outbreaks have been linked to a wide variety of foods, including fruit (melons), salads (coleslaw, corn, rice), dairy products (cheese, pasteurised milk, chocolate milk, 
butter), and meat/fish products (paté, hot dog sausages, deli meats, poultry, smoked fish). ${ }^{12,13}$ In order to trace the origin or vehicle of transmission in the current outbreak, whole genome sequencing of clinical, food, and environmental isolates is being done. Of 201 clinical isolates received since January $2017,85 \%$ are closely-related members of the same sequence type (ST6), representing a single strain of the pathogen. This suggests that there is a unique source of contamination of a widely-consumed food that is responsible for the outbreak. ${ }^{11}$ Needless to say, the priority for the investigators is to identify that food and its source.

\section{References}

1. Migliani R, Chanteau S, Rahalison L, et al. Epidemiological trends for human plague in Madagascar during the second half of the 20th century: a survey of 20 900 notified cases. Trop Med Int Health. 2006;11(8):1228-1237.

2. World Health Organization, Regional office for Africa. Madagascar plague outbreak: external situation report 14. Available at: http://www.afro.who.int/ health-topics/plague/plague-outbreak-situation-reports (Accessed 9 January 2018).

3. dos Santos Grácio AJ, Grácio MAA. Plague: a millenary infectious disease reemerging in the XXI century. BioMed Research International, 2017; Article ID 5696542, 8 pages. Available at: https://doi.org/10.1155/2017/5696542 (Accessed 9 January 2018).
4. Küstner H. Plague in Coega. Epidemiological comments. Department of Health, Welfare and Pensions, 1982;9(3):2-16.

5. Harvey Pirie JH. A new disease of veld rodents: 'Tiger River disease'. In: Mitchell JA, Harvey Pirie JH, Ingram A. The plague problem in South Africa: historical, bacteriological and entomological studies. Publ SA Inst Med Res. 1927;3(20):163-186.

6. Murray EGD, Webb RA, Swann MBR. A disease of rabbits characterized by a large mononuclear leucocytosis, caused by a hitherto undescribed bacillus, Bacterium monocytogenes. J Pathol Bacteriol. 1926;29:407-39.

7. Burn CG. Characteristics of a new species of the genus Listerella obtained from human sources. J Bacteriol. 1935;30(6):573-91.

8. Uniprot. Taxonomy - Listeria monocytogenes. Available at: http://uniprot.org/ taxomnomy/1639 (Accessed 8 January 2018).

9. Gibbons NE. Listeria Pirie - whom does it honour? Int J Syst Bacteriol. 1972;22(1):1-3.

10. Malan M, 1988. In Quest of Health. The South African Institute for Medical Research 1912-1973. Lowry Publishers: Johannesburg, p. 53.

11. National Institute for Communicable Diseases. Listeria monocytogenes outbreak update: ongoing detection of cases. Communicable Diseases Communique. 2017;16(12):6.

12. Datta AR. Listeria monocytogenes. In: Milotis MD, Bier JW, 2003. International Handbook of Foodborne Pathogens. Marcel Dekker: New York, pp. 105-21.

13. Ooi ST, Lorber B. Gastroenteritis due to Listeria monocytogenes. Clinical Infectious Diseases, 2005; 40: 1327-32.

Note added in press: A source of the current outbreak strain of L. monocytogenes has been identified as a commercial meat processing plant; outbreak updates available at www.nicd.ac.za 